\title{
本院最近工作概况
}

一、本院已接管的研究機構(包括西北科學考察橉 在內, 共有二十三個單位; 前中央研究院的数學、歷史語 需二研究所, 南京解放前遙合灣), 經過半年來的整理和

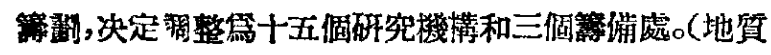

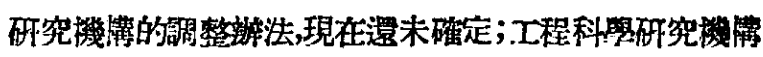

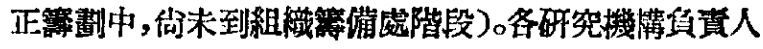

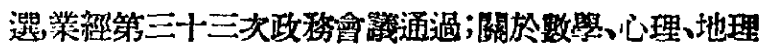

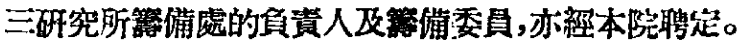
名稆
員 震 人
地址
1. 近代史研究所
所長：范交瀾
宗
2. 考占研究所
...所長：鄭振鐸
北
副所長：梁思永、夏 鼎
3. 善言研究㸫
...所長: 維常培
宗
4. 动會硼究所
所長：隐孟和
. 北 京
副所長：巫蛪山
5. 近代物理研究所
..所長：哭有部・
副所長：钱三强
6. 临用物理研究听
...所長：嚴濟甞
副所長：陸學善
7. 物理化學研究所
..所長：员學㓮
8. 仿機化盟研究所
所長：莊長恭.
藥物化學研究公
主任: 趙㧴椵
9. 生理生化研究听
...所長：馮德培
副所長: 王丝瞅

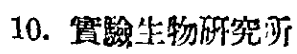
...所長：貝時璋...
副所長：音第周
植物生理研究空 ...主任：羅宗洛
發生生理研究室 主任: 朱 洗
11. 水生生物研究所
所長：王家瑁.
京
京
菒
海
海
海
海
副所長：伍獻交

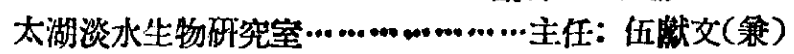
青島海洋生物研究室…………………主任：童第周(秉)
㓭主任：面呈奎、張 褧
12. 植物分類㸴究所
...所長: 錢紫澍
...北
副所長：吳徽鐙
13. 地球物理研究所
…所長：趙九章 ..南
副听長: 陳宗器、䪼功叙
14. 紫金山天文合
...台長: 張釷哲....
京
15. I學試驗舘
...舘長: ‘周
副舘長：周行健

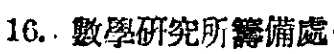
·主任委員：蘇步青
副主任委員：周培源、江澤涵、萿羅庚、許野瞰

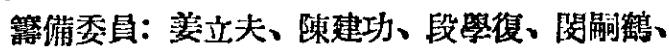
錢傹長、張宗傢、常 溷
17. 心理學研究所䇺俑處
主任委員：陸志韋.

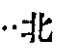
京
副主任委員：丁 瓚、陳 立、曹日昌
委員：潘 䔩、唐 鋮、孫國華、周先度、

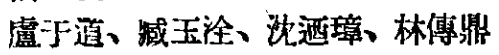

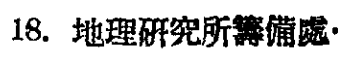
主任委員：竺可㡆
副主伯委員：黃霜維
委員：曾世英、係敬之、王之点、夏堅白、
方 俊、周宗浚、黄國璋、徐近之、李春恭、
周廷霹、王成組、劉恩關、周立三、羅開富 


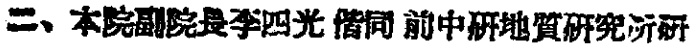

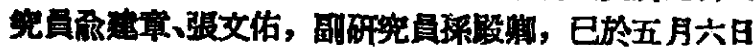

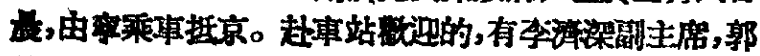

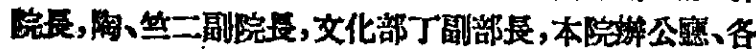

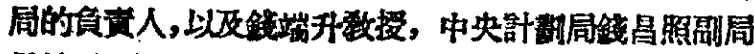

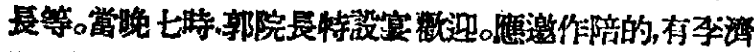

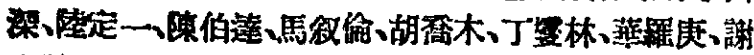

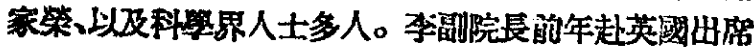

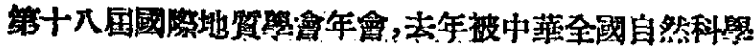

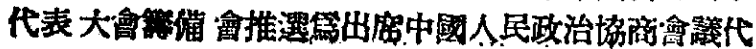

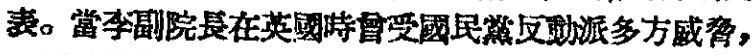

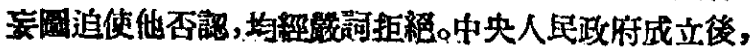
又旅任揙本院副院長。去年冬天，秘密襍英，被法國、瑞

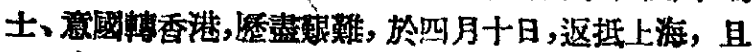

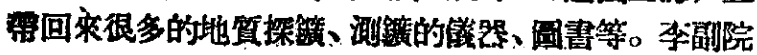

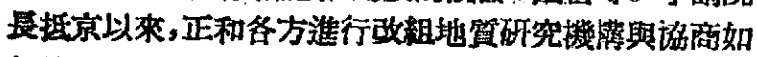

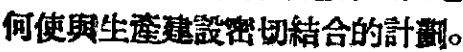

三、本院篇了嘹解東北生座建毁的望際情况，特組

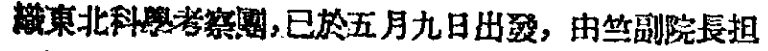

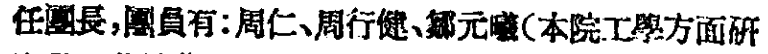

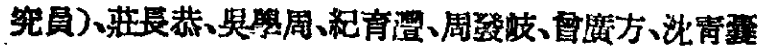

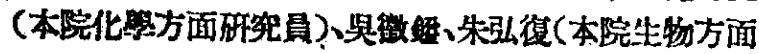

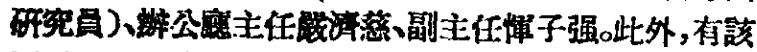

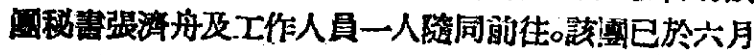
六日返京。

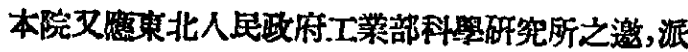

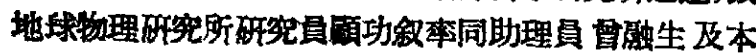

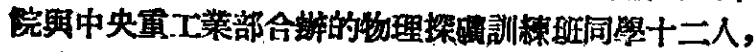

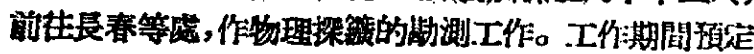
墭六调月。

本院南京地贫研究所研究員踰德洲、張文作，部研

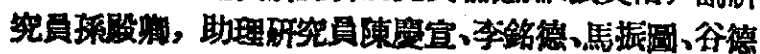

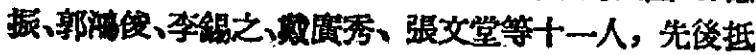

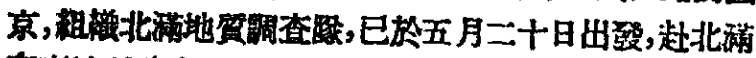

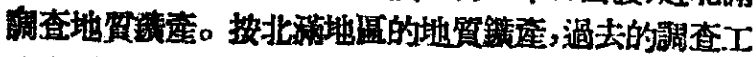

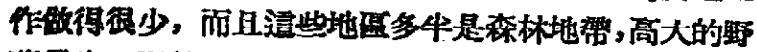

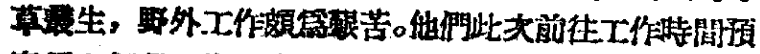

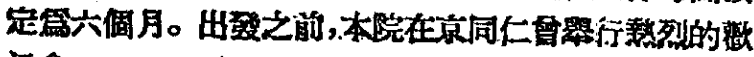
远金。

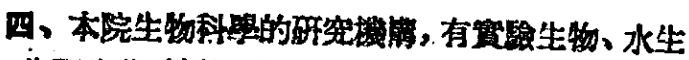
生物、生理生化、植物分類四倜研究的。其最近的工作， 略速如下:

\section{(一) 定酸生物研究所}

（甲） 嬁生生理研究害所注行的工作:

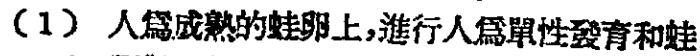
類隼胎的研究。

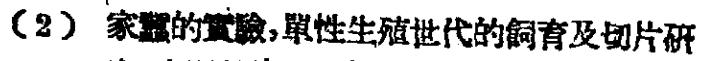

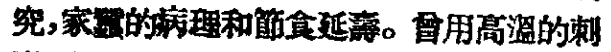

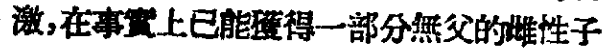

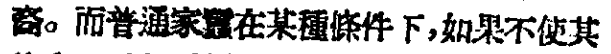
飽食, 可以延長其嗀命。

（3）結草虫 (Clanica ap.)的生殖生理及其細胞繁

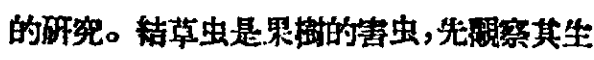
活史後, 今已研究其生殖腺的弦生順序及畉 的成熟和登育現象。

（4）水蛭 (Hirudo) 有否傅染疾病的性能。水蛭 能吃血, 常第别種傳染病等生出的中間宿 主。今㖟研究㷋, 在水蛭中,已检出睡病虫

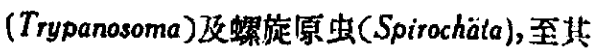
傳染能力㖵摄性問智，正在研究中。

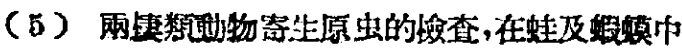
已检出寄生的缐虫有十多程。

(C) 棭物生理研究至:

（1）根㨜乲森科的春化法，將油荣、棉花、小慗、

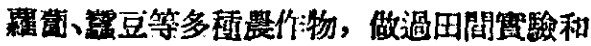

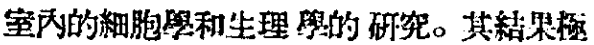

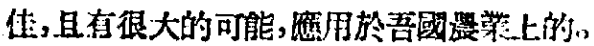

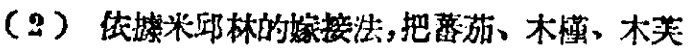

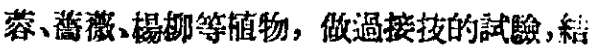
果地很圆游。

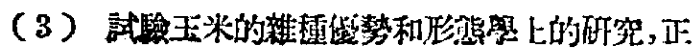
在進行中。

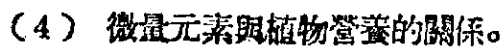
（二）水生生物䂣究所

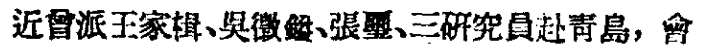

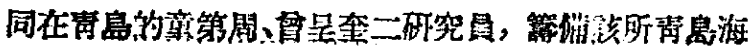

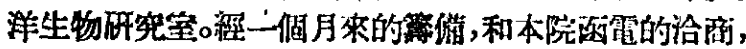

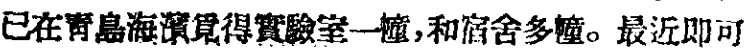

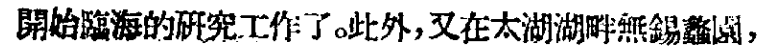
筧得大部长好居屋,作留太湖淡水生物研究室, 且已在

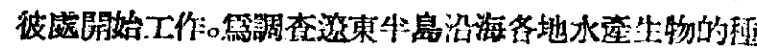

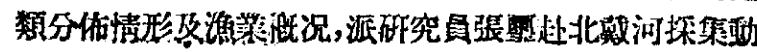

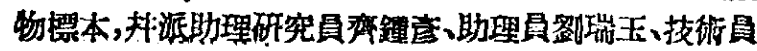

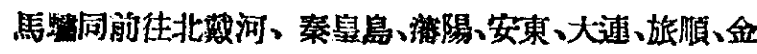

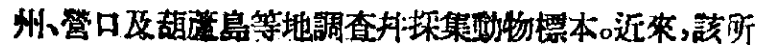
所做的工作略舉如下:

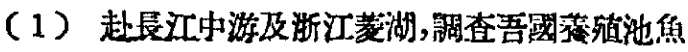

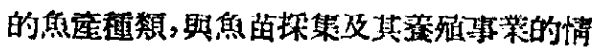
况。

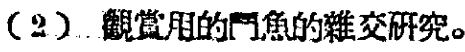

（3）水生昆虫對環境的適磼。

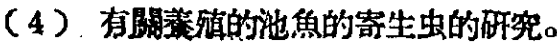

(5) 池魚的流行病與環境的成保。

(6) 成熟池魚生殖能力的研究。

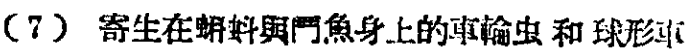
輸虫的蟣維柔綍的研究。

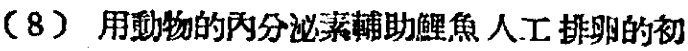
步䳝驗。

（9）太湖及其附近你池的水性和浮游生物的金䇫

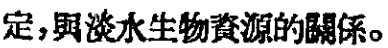

（10）青島近海的水性及浮游生物的鑑证與海洋 生物㗄源的閶俰。

(11) 西南淡水洴類的的究。

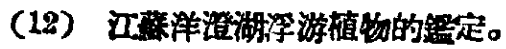




\author{
（13）海南島顿䇺動物標本的整理。 \\ (14) 樱蛕科的初步研究。 \\ (三) 生理生化研究所 \\ 最近的工作,略舆如下:
}

（1）神粨乾雷及鉀含显的測定 與神經極化變化 的關保。

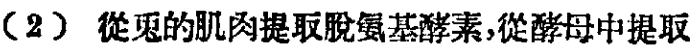
乙烧糖佐醉素。

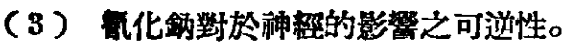

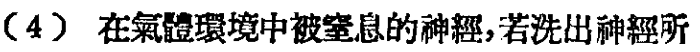
洩出的鉀，能在無唡的溶液中恢復其機能的 原因。

（5）瞕孔反射的神释管制, 脊神經笘細胞的復生 研究。

（6）小型電刺激器的撜計期製作, N-B 電子棘 激器的製作，G-E $3859770 \mathrm{G} 2$ 式层䢬器 的裝置。以上精巧誐器均作触經生理訌驗之 用。

（7）肌均的光概作用, 可促淮對疆硬作用的了 解。

（8）神經中釛原素的測定。

（9）色胺基酸在白鼠組織中的變成於草酸(維生 素B 之一)問題。

(10) 黃豆芽植物酸 (phytase) 的研究。

(11) 琥珀酸诵化酶素的研究。

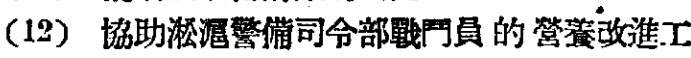

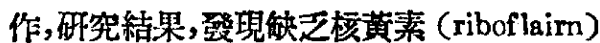

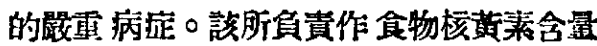

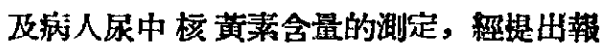

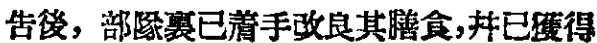
良好的效果。

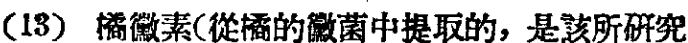
員汪跌所發明)的殺菌效用和其化篹棈造的 研究。

（14）配尼西林的結晶研究，接受茾東人民製菜跑 的委託而互相合作，已得到純粹的配尼西林 领筫和莱甲基配尼西林結晶的精椠品，回收 率可達百分之五十。

（四）植物分類研究听

穽了配合經濟建設，打下中國植物分類罢的基檚，

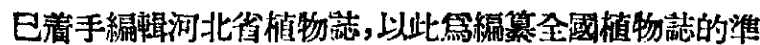

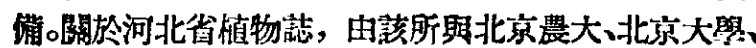

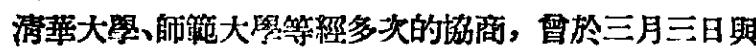
各大䍙的植物 分類專家與該所.工作人員開過一次座談 會，擬解具错計劃，設立永久性的河北省植物誌工作會

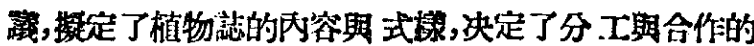

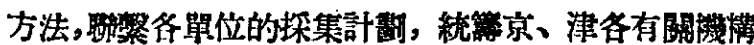
標本、圖書的互相流通合作使用。而且大部分糄祖和繪

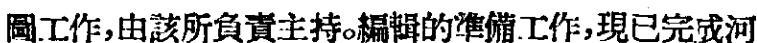
北省原產、哃見、鞂培植物名錄一册，包括河北省已知高 等植物一千入百餘種，已於五月二十日出版。另有術言 對熙及探集手訮正在編撰。植物誌的插圖也已開始繪

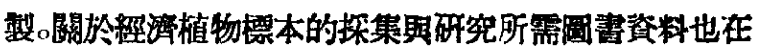
排集中。

在春季赛植物開花時節，該所曾至北京四郊及、上层 山、南口、十三陵等虎探集。最近又分批派員至河北省的 百化山、太行山南部、渤海深鹪橙本。關於其他的工 作, 略舉如下:

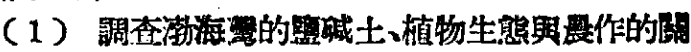
係。

（2）整理該所附設的植物圆和苗图，移佼它對研 究工作及通俗科學数育能發生作用。

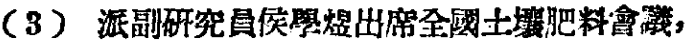

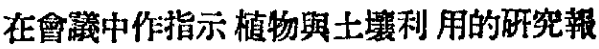
告。

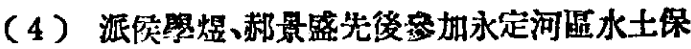

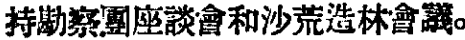

(5) 編晖察船植物誌。

(6) 編篹上海郊逷植物誌。

(7) 西康商用靯材的木材構造。

五、本院物理及化学方面的研究機清有近代物理、

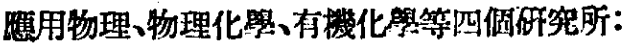

(一) 近代物理研究所

歴史較淺，大部分儀器台贸在.上海、南京，末運到。 現在中心的工作是延聘專家和培羡青年研究.工作者。最 近的工作,略舉如下:

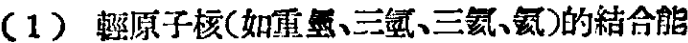

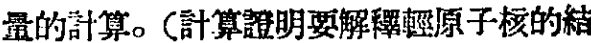
合能量，核子之間的基本作用必需偕助於管 電介子與中性介子的雙䨘媒介作用,中性介

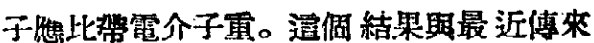
的國外贯驗結桨完全符合。)

（2）原子核結合能量的新的伴經驗公式。

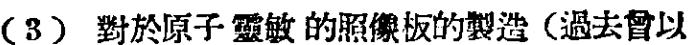
此種照像板發現釗原子核的三部與四部分 裂)。

(4) 裝置一個自製的威爾遜雲室。

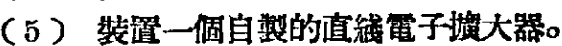

（6）盢原䁈的分裂法。

(7) 新的原賀表的編裴。

(二) 憵用物理研究所

該所過去設備較有基碟,在上海、南京的機腈，暑假 中,均將北遷。最近的.工作是:

（1）龄金䔽溶液中微量雜賀的分析。

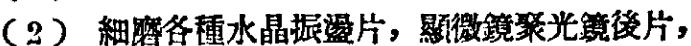
一百倍物鏡後組凸透鏡，物鏡的片。检定水 晶的光軸及䉓軸。

（3）冶金顯微鏡聚光鏡部分的計算。

（4）銅和一價集化銅中間的單向性湍電現象。

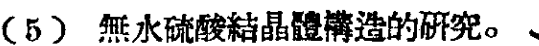

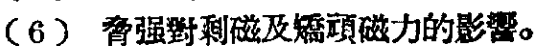

（7）金屬單結晶的製造。

(三) 物理化學研究所

最近的工作是:

第二期科學通報 


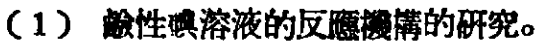

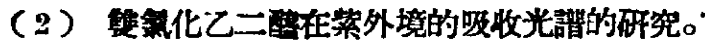

（3）電煌條外居勧料的分析。道是接受中國人民

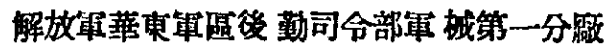
的委託, 分析武器染料的成分。已將分析結 果報告後勤司合部。

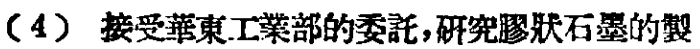
借方法,已得成功。此物笉然線電製透過程

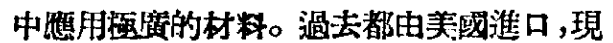
在必须自筡了。

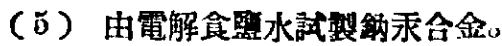

(四) 有機化罢研究所

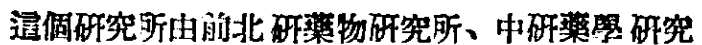
所扎研化罢研究所及中研化照研究所的一部分合併而 成,到現在份未政組就粕。今将以上四個研究機幥,有關 有栋化照的研究工作，略舉如下:

（1）接中央重.工業部化.工局的委託，代笉試驗 包頭天然塂的棈製方法。已將試驗成功的 結果,報告化工屁。

(2) 南京華東贯業科學研究所的委託, 試暂

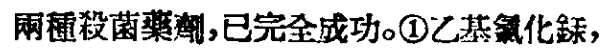

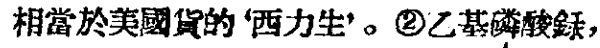

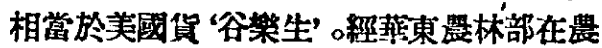

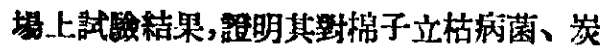

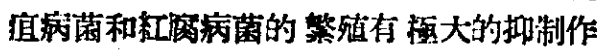
用，對其胞子有缮隇的效用，且輘美國货更 强。

(3) 中国苦貝母的化照研究。

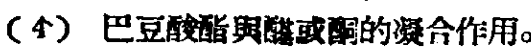

(5) 國菜桔梗中的有效賀素的研究。

(6) 抗熱配尼西林白色結晶的製造。

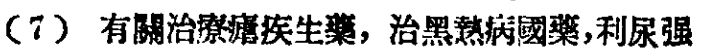

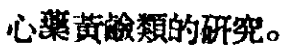

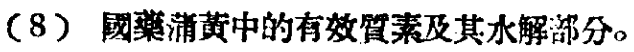

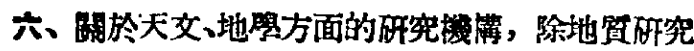
所未决定外,有紫金山大文合、地球物理研究所、地理研

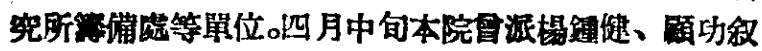
二言家加知料工莱部所召開的全國不油會破,以便了 解石油事業的情况。

(一) 紫金山天文台:

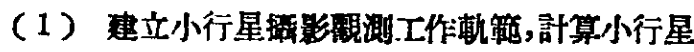
的赤释赤緯。

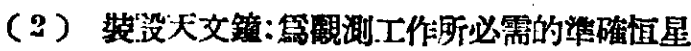

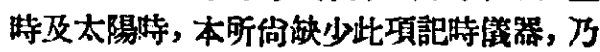
將残破的雪特式天交鐘一套,運至上海徐家

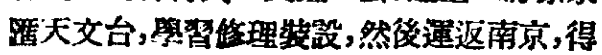
中研物理研究所的期,乃把雨架天文鏡裝

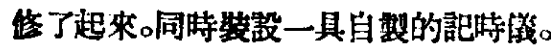

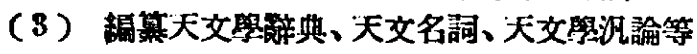
書籍。

（二）地球物理研究所

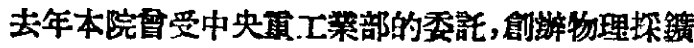

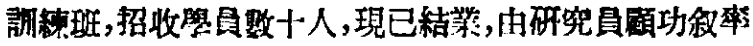

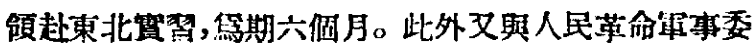
員渝氣像局合作，在京、窑二地都取得密切的聯㢣，從事 氣像情况的工作。

關於其他的研究工作:

(1) 東亞大氣環流期天氣形计的研究。

（2）中國東部水旱原因的探䇣。

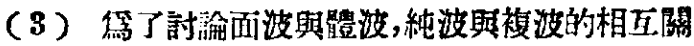
係, 预研究瑞雷方程次要根之物理意莪, 已 得有絬果。

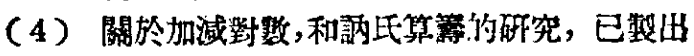
模形一種,供諸惯用。

（5）地磁記錄義隼置的改善。

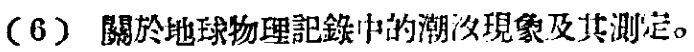

（7）中國的地磁場以及地磁岡的解製，

（三）地理呼究听符備處

最近的工作是:

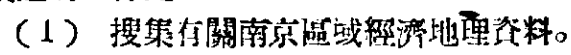

(2) 調查南京上新河的木材甫場。

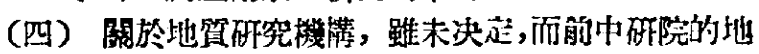
質研究所在最近幾個月来的工作, 路分批越東北北湤及 華東進行地筫調查工作外，略述如下:

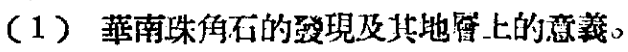

（2）四川省中生代的植物化石。

(3) 淮陽山胍的岩石籍物。

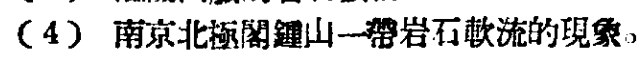

(5) 江西虔南大吉山的銍筑。

(6) 賈汪的煤田。

(7) 浙江北部地貿構造的輪碚。

七、關於工程科照的研究機灌, 在上海存一個工 學害捡舘，其最近的工工作是:

(1) 山東金婈鎮含銅磁鐵等的分析。

(2) 䥂鐵組織的研究，

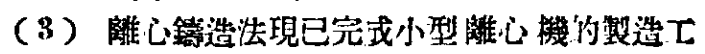
作，

(4) 化罢登的試製。

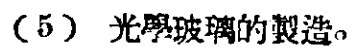

(6) 沙型筑造法的研究。

(7) 天然石畧的精碀。

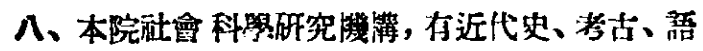
霅、社會等四個研究所。近代史研究所是以前華北大照 研究部,此所的工作近况将另行報等。

(一) 考古研究所

已在安陽正式進行發堸工作。在安陽“泪盤磨”西探 得可以工作的墓葬十四處, 小电唒温三十就地‘中灰土

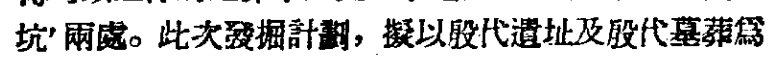
主，間及史器彩陶黑陶遗址。四月十八日鮛腃考占專家

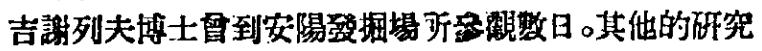
工作, 略述如下:

（1）䍌過去十五次的段墟没堸工作，做一個總俭 㐨。此論交將着手宾出。

（2）吐急番及塔里木盆地的考古材料的整理。 
(3) 閏墔台瓦弇墓的年代間題。

\section{(二) 語言研究所}

過去的中研歷史語穹研究昕北京圆書史料整理處， 曾做渦中古習語的研究。至於詳細情况, 待新的研究所 正式開始工作後,另行報算。

（三）社會研究所

最近該所研究人員大部分都到華北革命大壆政治

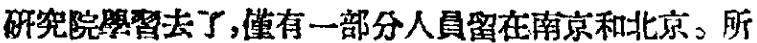

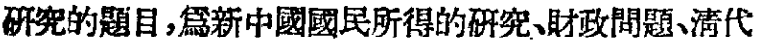
酒傕史等。

九、本院腭劃局最近的工作，除了調整本院所犀 的究機櫣外,有下列备項工作:

（一）專家铜查：經過數月來的調查和 备專家的 推荐,已選定在國內的自然科學工作者一百六十五人琶

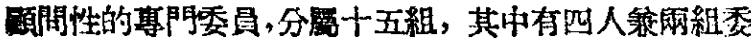
員。專門委员的主要任務是勢助本院計撞各所研究.工作

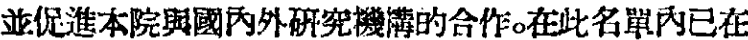
本院的工作人員，不另行聘請。專門委員名咊如下：(沄 曾科學部門專門委員份未决定)。

1. 数 學 組: 江澤涵 周培源 姜立夫 段學復

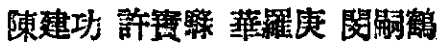
銭傹長 独步青

2. 近代物理組：王竹溪 王涂昌 吳有訓 何澤慧 周培源 張宗檖 彭桓武 趙忠堯

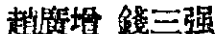

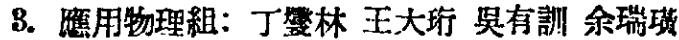

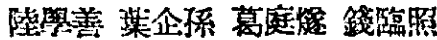

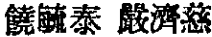

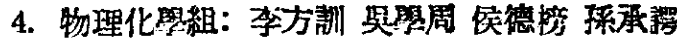
棌然悟 張蔳葏 黄子瑯 惲子强 盧塞錫 錢人元

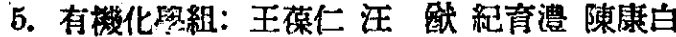

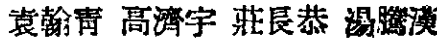
既昭掄 㛫石先 趋㗊

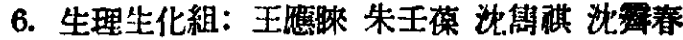
易見凊 徐豐登錫鈎 馮德培 趙以两 蔡 整

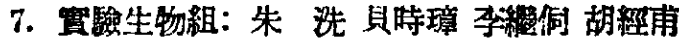

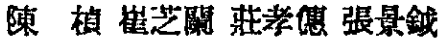
童第周 晹㑣松 劉禁樂 羅士草 羅宗洛

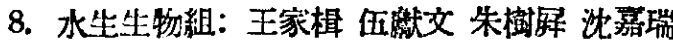

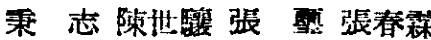

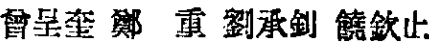

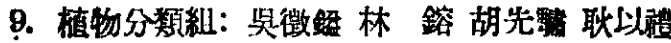

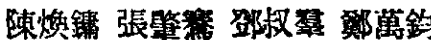

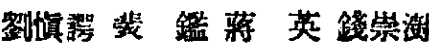
芳润

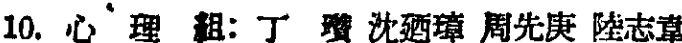

唐 鋮 係國華陳 立曹日昌 潘 䓩”践玉洤

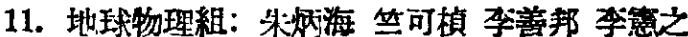

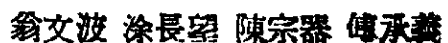
趙九章虚 盕 碩功叙

12. 地 留 組: 王仡泉 田奇谯 季四光 李春景

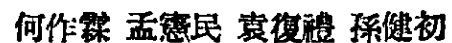
疋德封 郭交蜼 黄没清 張文佑 章鸿釗 程裕淇 謝家策 瀷錫腈

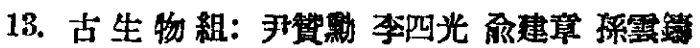

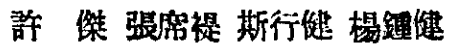

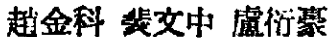

14. 地 理 粗: 方 俊 王之卓 攀旭且 攀㫪苏 竺可楨 周立三 周宗爷 徐近之 夏堅白 採敬之 黄策維 黃國璋 曾世英 劉恩叞 䑾開䈏

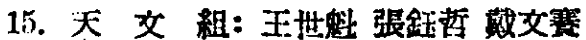

（二）自然科學工作者的調查: 根揣中茾全國自然 科累工作渚代表大會籍借的登記表, 和過去南京解科 照促淮:會的調查表, 本院已作了初步的粽合続計。所得 资料共約一萬五千人。第一步先選擇其學㧓水平輘高者 一千三百多人抄入表格,作胥本院的存资料。

（三）本院条粐研究人員工作耚驗、著作目錄和著 述的搜集

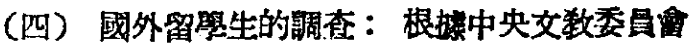
留學生回國事務委員會的報告和材料，編成一㮔表 格。

（五）全國科祭研究機構的調 查, 已得有初步結 果。

（六） 全國專科以上祭校既况的調查：曾派 員赴

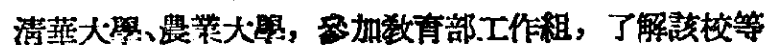
研究所和綪的助的工作情况。每次铜查皆歴一週之 久。

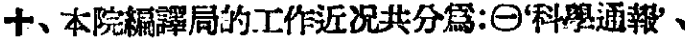

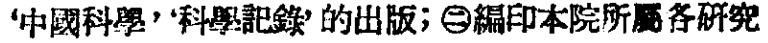

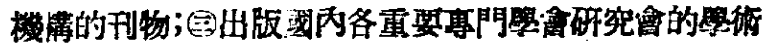

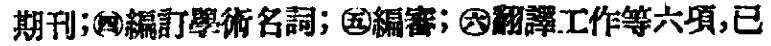
另有專文報告於本期通報內。

十一、本院聯䊀局的最近工作:

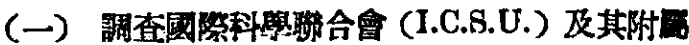
各學會，包括天文、地理、地球物理、化學、無缐電、生物、

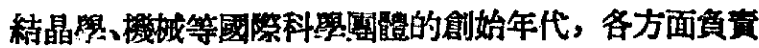
人,會址,主要活地，出版物等。

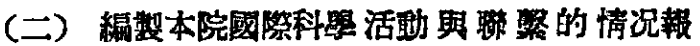
告。

（三）委託外交部請捷克、波橮、德國、匈牙利、保 加利亞、羅、馬尼亞、朝鲜等新民主主義國家的大使舘代

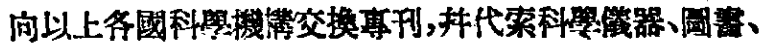
菏品目錄。最近已收到柏林德國科學院寄来七十二種科 照新交。

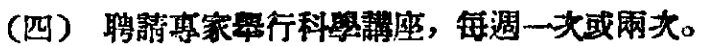
网個月來, 共已舉行六大。地點多在北京中法大照视堂

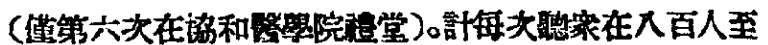
一千人以上,情緒頗霑熱烈。

第二期 


\begin{tabular}{|c|c|}
\hline 椿 & 通 \\
\hline 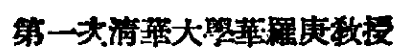 & 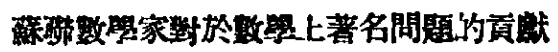 \\
\hline 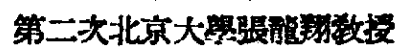 & 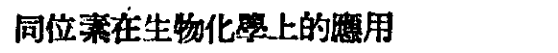 \\
\hline 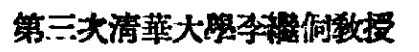 & 米邱林的工作介稆 \\
\hline 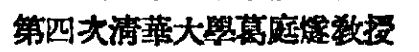 & 金盛的强度 \\
\hline 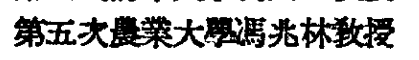 & 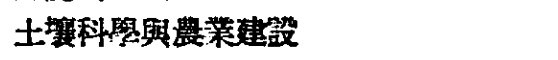 \\
\hline 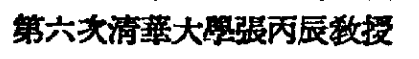 & 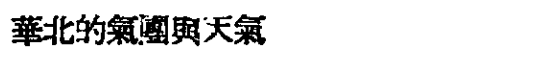 \\
\hline
\end{tabular}

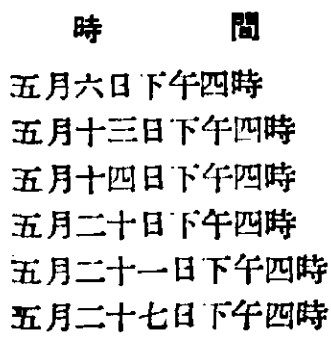

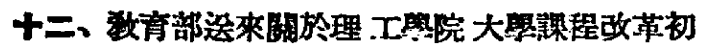

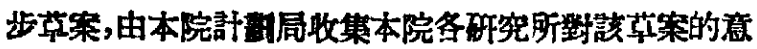

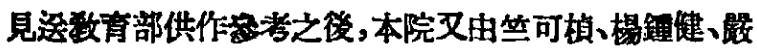

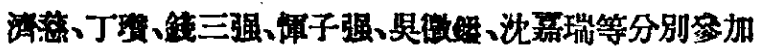

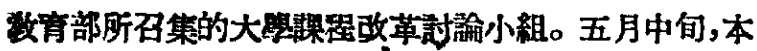

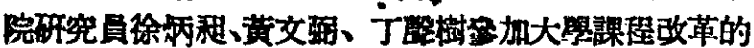
歴史地理小数的徍諭。

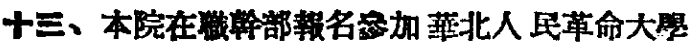

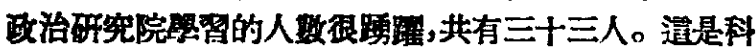

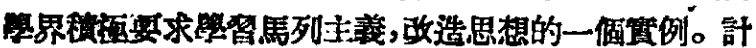

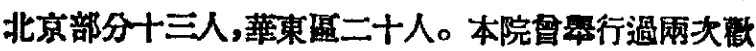

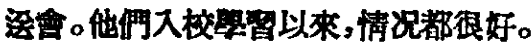

十四、本院全院猫.工人数至五月厎止，共有862人。

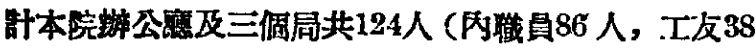

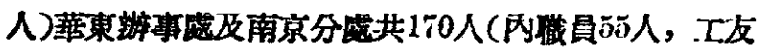

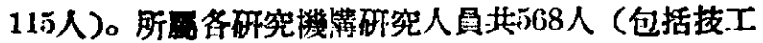
等)。

十五、本院預定六月豪 在北京交津街三號一一本・

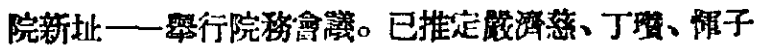

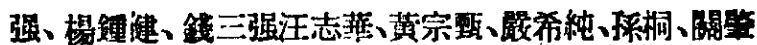

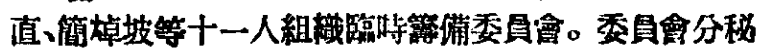

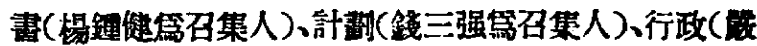

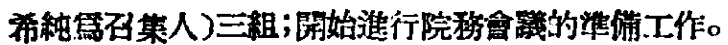

十六、本院在京翰部的政治罗㚙,早已開始。分成

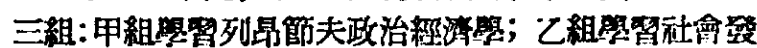

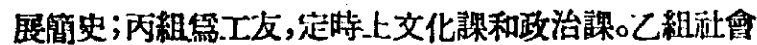

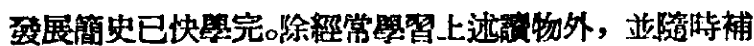
充重要交件，如中蘇友好助互同盟條的等。最近，腊望完 了埕副主原“五一”幹部會上的演镜。

(完)

\section{哈爾濱農學院農林植物調查所工作近况}

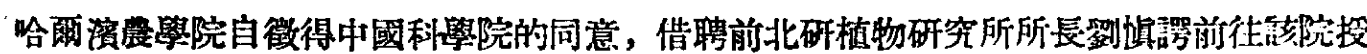

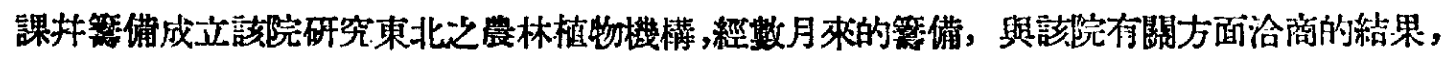
工作程序,已進行至下列情况:

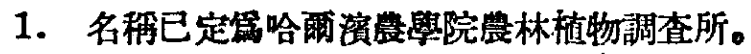

2. 工作人員已有八人，計数授資歴者二人，列教授資歷者一人，助教資歴者五人。暑假前 可能再增加五、六人至十数人不定。

3. 本年工作重點放在採集與調查雨方面; 探集工作將探用普通搜集方式,高等植物與但

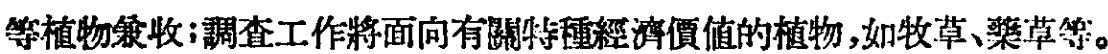

4. 本年探集及調查地點，已內定南北滿分八個代表區。希案弡動本所全部人力，由本年 四月下旬至九月前後,共約五個月期間, 分期分批進行。期於本年秋後對堡北汒天然 植物资源得一概念或有初步的輸涯。

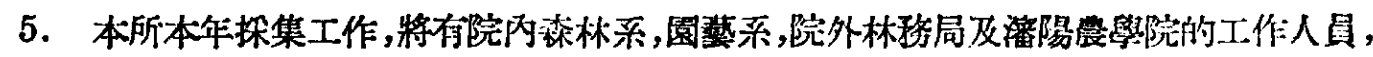
同時寥加。

6. 本年探集用具及用品,大致已籍借竣事,四月下旬,即將準亚出發。

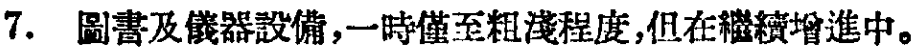

8. 房舍設倩，鼠校已决定新建一所佔二千至二千五百平方公尺地面的三居掼房，生物 舘不日即可閙工。

（㓣稘諤） 